\title{
Weather Extremities, Challenges and Risks in Hungary
}

\author{
KUTI Rajmund, ${ }^{1}$ NAGY Ágnes ${ }^{2}$
}

\begin{abstract}
Extreme weather events are demonstrating their effects more and more increas-ingly in Hungary due to global climate change. To be able to lessen damages and implement effective preventive measures, or eventually perform defense and a fast, complete relief project, we need to study these phenomena and explore their effects. Another important task is the scientific investigation of direct impact on envi- ronmental factors and humans, analysis of the results, using gained experience for preventative or if needed, remedial activities. With this article our aim is to draw attention to the importance of being aware of the extreme weather events and its effects. With this comprehensive knowledge, disaster management can elaborate appropriate responses for preventive and rescue challenges.
\end{abstract}

Keywords: global warming, climate change, extreme weather events, preventive action, remediation

\section{Introduction}

Negative impacts caused by global warming occur more and more, year by year in Hungary as well. Climate change in our country led to more frequent extreme weather conditions, causing more cases of destructive, stormy wind, deluging rain, snow storms and major tem- perature fluctuations. [1] However, these sudden weather changes cannot always be predict- ed, therefore it is difficult to prepare for the protection and mitigation of losses, thus damage prevention poses new challenges for professionals. Recently, these events have caused se- rious damage in several inhabited areas of Hungary, and tackling these consequences was a difficult, complex and expensive project. [2]

By analyzing the impact of weather extremities on natural and artificial environment and remediation efforts taken to mediate their consequences, we can conclude that more precise knowledge of these phenomena, preparation for damage elimination, and experience of orga- nizations involved in loss prevention can provide useful basic information by different types of catastrophes.

\section{The Consequences of Global Warming}

Global warming is the increase in Earth's average temperature, consequently causing tem- perature increase of the oceans and air near the surface. In the past decades, our planet's climate has changed significantly, but even today the role of human interference is debated.

1 Ph.D. (Military Technology), University of West Hungary MÉK - Environmental Sciences Institute, e-mail: kutirajmund@t-online.hu

2 MSc student, University of West Hungary MÉK - Environmental Sciences Institute, e-mail:

agnes.nagy.keki@gmail.com 
Global temperature increase leads to environmental changes, rise of sea level, changes in quantity and geographical distribution of precipitation and extremities of weather conditions.

These phenomena have a significant impact on the productivity of agriculture. It has a major influence on the economy, reduces the gross domestic product of the countries con- cerned, and could affect its quality. [3] We should reckon upon drying of natural waters, melting glaciers, with floods, hurricanes and typhoons becoming more frequent, bigger and more devastating. Extinction rate of animal and plant species increases, while certain inva- sive species thrive that upsets ecological balance. Certain diseases spread more easily, more maladies thought to be "tamed" can reappear also as mutant variations. These changes might vary in different geographical areas. [4]

Data collected by the United Nations Intergovernmental Panel on Climate Change (IPPC) shows, that the average temperature of air near the surface has increased between 1905 and 2005 by $0.74 \pm 0.18^{\circ} \mathrm{C}$. According to the Panel the main reason is the emission of greenhouse gases into the atmosphere from the middle of the $19^{\text {th }}$ century onwards. These gases cause the warming of the troposphere, the lowest layer of the atmosphere. Researchers debate fiercely to what extent warming is caused by natural influence (increasing solar radiation, volcanic activity, changes in the Earth's orbit), or by human activities. The most accepted studies, sci- entific consensus papers agree that global warming is due to human-induced changes.

This is supported by calculations, showing that solar and volcanic activities are presently working against global warming. Climate models adopted by IPCC show that the Earth's surface temperature will increase approximately by 1.1-6.4 ${ }^{\circ} \mathrm{C}$ between 1990 and 2100. Al- though most of the studies calculate until 2100, warming can continue afterwards, sea levels can keep increasing even when emission of greenhouse gases stops, as carbon dioxide (CO ) remains in the atmosphere for a long time. [5]

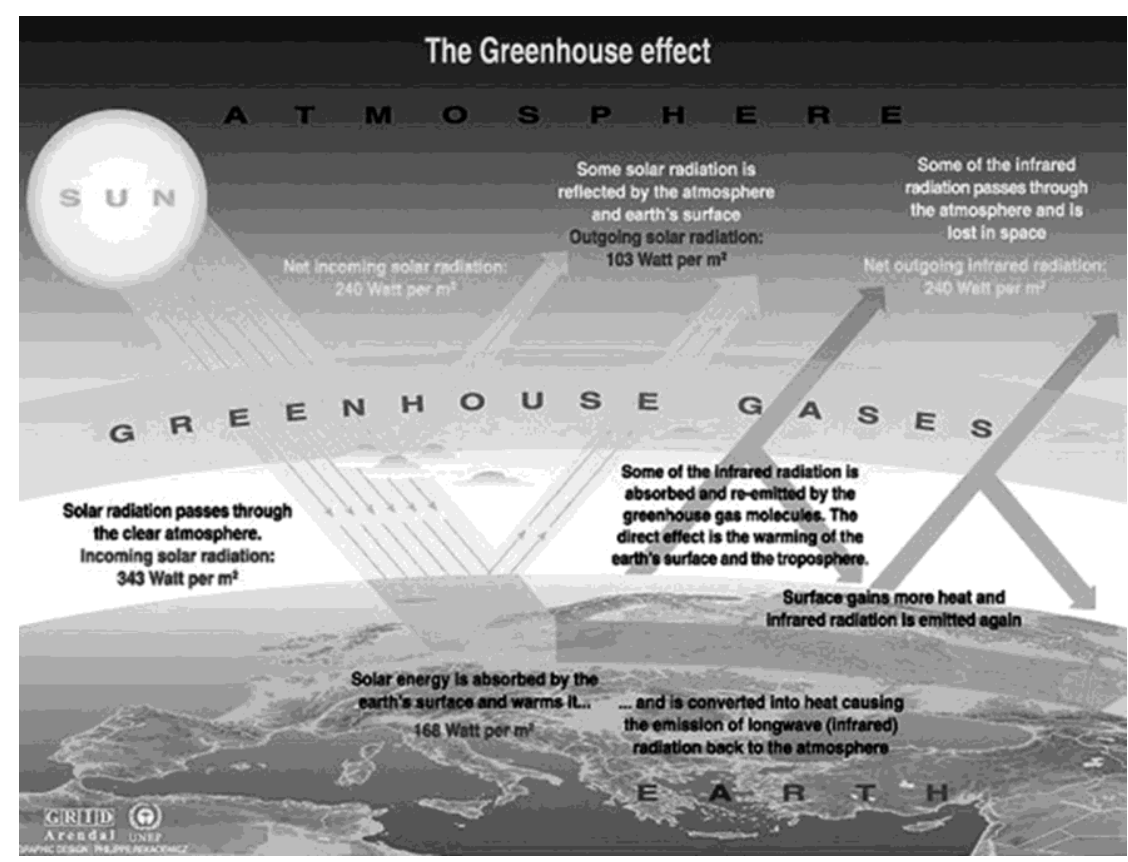

Figure 1. Overview of the Greenhouse effect. [5] 


\section{Manifestations of Extreme Weather in Hungary}

\section{Deluge}

Meteorological forecast of weather extremities is not an easy task, so preparation for de- fensive actions is not simple. [6] As Hungary was flooded several times in the past years, we could study experience gained during fending off possible damages, which are the most important steps of remediation.

Violent rain is characterized by a huge amount of precipitation in a short period of time, when volumes overload the drainage system, and accumulating water inundates the grounds. Drainage can be facilitated and solved in most places by trenches and suction pumps, but in some low-lying areas the use of sandbags might be necessary. In most cases remediation is performed by units of professional organizations, but shortage of capacity and resources might need involvement of local governments in protective activities. [7]

\section{Windstorm}

In most cases windstorms can be predicted, therefore the public should be informed about preventive measures to decrease casualties. As windstorms have caused serious damage sev- eral times in the past few years in Hungary, experiences gained from the removal of damage, practical information and descriptions provide specific clues for future defensive actions.

The windstorm is characterized by longer or shorter periods of exerting its impact, it twists trees, breaks branches, tears off roofs, damages electric and telephone networks, can cause accidents on roads and railways. In most cases remediation is performed by units of professional organizations in full accordance with the required safety measures. [8]

Wind speed can be categorized as seen in the chart below.

1. Table: Wind speed. [8]

\begin{tabular}{|l|c|c|}
\hline \multirow{2}{*}{ Category } & \multicolumn{2}{|c|}{ Wind speed } \\
\cline { 2 - 3 } & $\mathrm{m} / \mathrm{s}$ & $\mathrm{Km} / \mathrm{h}$ \\
\hline Doldrums & 0 & 0 \\
\hline Light wind & $1-3$ & $4-11$ \\
\hline Moderate wind & $4-7$ & $15-25$ \\
\hline Brisk wind & $8-11$ & $29-40$ \\
\hline Gale wind & $12-16$ & $43-58$ \\
\hline Stormy wind & $17-24$ & $61-86$ \\
\hline Strong stormy wind & $25-32$ & $90-115$ \\
\hline Gale force winds & $33<$ & $119<$ \\
\hline
\end{tabular}




\section{Heatwave}

The European Commission's Green Paper, among many other factors, draws attention to the health-damaging effects of heatwaves. For protection of the citizens it is therefore extremely important to have a scenario in place for measures to be taken during heat alert.

Hungary's population includes a large number of highly endangered (vulnerable) groups who spend extended periods of time or stay permanently outdoors during heatwaves. During the summer season a lot of sporting events are organized in the larger cities of our country. We must take into consideration how outdoor sports events and other programs taking place during heatwaves can be managed without hazards to our health, how to protect those work- ing in the open air, their fluid replenishment, relaxation in shadowed area, or attire during work. [9]

According to environment and environmental health considerations, those public utility and residential services will be prioritized, which influence not only the quality of the envi- ronment but also people's living conditions for the better or for the worse during heat.

Especially protected are drinking water bases, strategic drinking water reservoirs and pipeline systems, where operating companies provide good quality drinking water for the population. In case of power blackout during a heatwave, there is an average 2-3 hours shut- down, but still all customers are supplied. Prolonged heat can increase demand for energy, which might possibly lead to the implementation of restrictive measures.

As our country is a transit country, it is important during heat, that the threats to the trans- portation sector should not be overlooked. Even an emerging minor malfunction of railways can result in major disruption. Excessive heat can cause deformation of the trails, dilapida- tion of overhead wires and supporting columns. In case of temporary cessation of rail trans- port, train stations must accept travelers, while their onward journey is not warranted. During this time, their uninterrupted supply must be ensured. Several municipalities are affected by the highways and main roads as well. Persistently elevated daily average temperature can lead to higher incidence of accidents on the road sections concerned. Fluid supply for trav- elers trapped because of developing traffic jams should be provided. Public transportation company vehicles operate continuously even in prolonged high average daily temperatures. On newer vehicles air conditioning, on older models continuous ventilation and fans provide protection from the heat for the passengers. [10]

In most cases heatwaves can be predicted, therefore the public should be informed about preventive measures to preserve health.

Heat alert is a warning issued by meteorological services and the competent authorities because of above average temperature measurements and expected higher mean values. In Hungary, heat alert was introduced by the National Institute of Environmental Health and the Office of the Chief Medical Officer in 2005, and is part of the weather warning and fore- casting system. [11] The heat alarm temperature values may differ from country to country.

- Stage 1. (Information stage): The condition of ordainment is that forecast, and daily mean temperature must exceed $25{ }^{\circ} \mathrm{C}$ for at least one day. At this stage, the National Public Health Service sends their information to county organizations. In this case lo- cal and regional authorities may inform the public about expected weather conditions through their own media channels. 
- Stage 2. ( $1^{\text {st }}$ grade alarm): The condition of ordainment is that the daily mean tempera- ture must exceed $25^{\circ} \mathrm{C}$ at least on 3 consecutive days. For second-stage heat alert the National Public Health Service informs health institutions, ambulance services, GPs and local authorities about the extent and duration of the heat alarm. Thereafter it is the municipalities' task to warn the population and prepare protective action against heat-caused damages.

- Stage 3 ( $2^{\text {nd }}$ grade alarm): Its criterion is that the daily mean temperature must exceed $27{ }^{\circ} \mathrm{C}$ for 3 consecutive days. In this case, besides all second stage alarm measures, the public must be informed through the media about expected weather extremities and potential methods of preventing heat hazards.

National Weather Service codes for high temperature alarms:

- Yellow alert: Temperatures above $33{ }^{\circ} \mathrm{C}$ expected over larger areas

- Orange alert: Temperatures above $36^{\circ} \mathrm{C}$ expected over larger areas

- Red alert: Temperatures above $40{ }^{\circ} \mathrm{C}$ expected over larger areas

\section{Extreme Cold, Snow Storm}

In most cases snow storms can be predicted, therefore the public should be informed about preventive measures to preserve health and mitigate damages. The blizzard is characterized by exerting intensity over shorter-longer time intervals and if coupled with long-term ex- posure to cold, it damages electric and telephone cables, is likely to create disturbances in district heating and drinking water services, can cause disruption, accidents on roads and rail- ways. In most cases, damage repair is done by professional liquidator units, in cooperation with the law-enforcement bodies and military forces.

\section{Prevention, Preparedness Related Tasks}

Great emphasis should be placed on prevention, however there are disasters, which cannot be prevented (meteorological disasters), but fast, efficient and complex damage recovery can be prepared for, with planning of defense tasks for the sake of the cause. It is advisable to draw up an inventory of municipality owned machinery, tools needed for defense, which are available for local use. The lists are managed by local governments, and should be revised on an annual basis. Preparation can be facilitated by practical advice and assistance from professional disaster protection organizations. It is advisable to be prepared for damaged areas affecting several villages or large expansions, or when damage repair will be a long- term process. Effective defense is based on fast and comprehensive assessment of the nature of the damage, determining the extent and the sequence of actions needed in order to ensure effective remediation. It is important to prepare the members of the defense committees, as they have to take part in the defense. Inventory lists of existing forces and tools should be updated, so they can be made available in the shortest possible time.

\section{General Defense Tasks}

In some extreme cases, when rapid intervention is unavoidable (large areas, multiple zones are affected by catastrophic situations, the professional units cannot begin salvaging within 
a short time frame), the control process should be conducted, arrangements for transporting listed forces and tools to the location and summoning the defense committee should be done. Planning and implementing a complex remedial operation is a compound task. [12]

When issuing alarm for protective actions, it is reasonable to include replacement re- sources, as staff shortage due to a variety of causes could occur and should be calculated with. Alarmed forces and tools should be directed to the appointed assembly point, a place preferably in the vicinity of an actual worksite. They should be briefed about all aspects of the job to be done, expected duration, and an on-the-spot manager should be appointed, whose name, telephone number should be recorded, and this person should have all impor- tant details needed for continuous contact. In case of need, relevant institutions, neighboring municipalities should be contacted about relocation, reception and accommodation issues. Those in need of constant medical care should be reviewed, medical coverage and perchance transfer should be provided for. Public utility providers should be notified. The president of the Defense Committee and disaster management organizations should be kept informed about all events at all times.

\section{Communication Issues}

During protective actions emphasis must be placed on correct information to the public, on appropriate communication. Crisis communication is the process when a security manager or designated person informs the concerned, the defined target groups in a timely, factual and well-suited form about the current situation.

This may take the form of written communication or personal speech. It could be a state- ment, a press conference, an announcement, briefing and interactive communication. The priority is media management. Media distorts. It is important to complete these distortions with relevant data, real and evidence-based information. [13]

\section{Recommendations}

In this article we collected, systematized and analyzed the most commonly occurring ex- treme weather events in Hungary, also the remedial experiences thus allowing formulating useful recommendations for future generations. Speaking as regards all phenomena, it is indispensable to comply with the statements in the official information and publications. It is also important to take place in remediation as a citizen, and to help the professional damage removal organizations, local government's activities. Furthermore, continuous assessment of the situation, analysis of the experience is as well a major task as a result to increase the effectiveness of protection work in the future.

\section{Conclusion}

Common feature of catastrophes is that they affect large areas and large number of people. Thus preventing them, preparing for remediation of the damages they cause, saving human lives and material matters, implementing the mustbe-done immediate reconstruction works should be followed with raised attentiveness. Local governmental institutes play an import- ant role in defensive actions against consequences of catastrophic events. 
We have chosen the discussed topic as how the efficacy of actions to be taken against the damages caused by extreme weather conditions could be increased, that is an important current issue. We have highlighted the importance of prevention and preparation, and de- scribed situations of meteorological catastrophes occurring most frequently in our country, in a practical manner.

We hope to draw attention to elaborate preparation needed for protection from damaging effects of extreme weather conditions, the importance of informing the public, which are essential for effective remediation.

\section{References}

[1] FÖLDI L., HALÁSZ L.: Környezetbiztonság. Budapest: Complex Kiadó, 2009. [2] KUTI R.:

Extrém időjárási jelenségek kockázatai, a védekezéssel kapcsolatos önkormányzati feladatok. In. Önkormányzati megoldások a hatékony müködés jegyében, Complex-Figyelö Önkormányzati Konferencia. Budapest, 2011. 11. 23., 1-25.

[3] HALÁSZ L., FÖLDI L., PADÁNYI J.: Climate change and CBRN defense. Hadmérnök, VII 3 (2012), http://hadmernok.hu/2012_3_halasz_padanyi_foldi.pdf 42-49. (downloaded: 1303 2015)

[4] PADÁNYI J.: National defense research on the effects of climate change. Hadtudomány, 1 (2013), 30-40.

[5] IPCC Working Group 1 contribution, Science of Climate Change, Second Assessment Report, 1996.

[6] Országos Meteorológiai Szolgálat honlapja. (downloaded: 1512 2014)

[7] KUTI R.: Intézkedési program belvíz-védekezési munkálatokhoz, Védelem Online, Tüz-és Katasztrófavédelmi Szakkönyvtár, 67 (2007), 1-12. (downloaded: 1303 2015)

[8] KUTI R., FÖLDI L.: Extreme weather phenomena, improvement of preparedness. Hadmérnök, VII 3 (2012), 60-65. http://hadmernok.hu/2012_3_kuti_foldi.pdf (downloaded: 1303 2015)

[9] KUTI R., FÖLDI L.: Extreme weather phenomena 2. The Process of Remediation. Hadmérnök, IX 2 (2014), 250-256. http://hadmernok.hu/142_23_foldil_kr.pdf (downloaded: 1303 2015)

[10] KUTI R.: Extrém hőség hatásai elleni védekezés önkormányzati feladatai. Védelem Online: Tüz-és Katasztrófavédelmi Szakkönyvtár, 495 (2014), 1-4. (downloaded: 1303 2015)

[11] Állami Népegészségügyi és Tisztiorvosi Szolgálat honlapja. www.antsz.hu/hoseghullam (downloaded: 2003 2015)

[12] KUTI R.: Komplex müszaki mentések tervezésének lehetőségei. Védelem Online: Tüz-és Katasztrófavédelmi Szakkönyvtár, 233 (2010), 1-7. (downloaded: 2003 2015)

[13] FÖLDI L.: Impacts of climate change to disaster management tasks with special emphasis on critical infrastructures. Hadmérnök, VI 3 (2011), 50-57. (downloaded: 2003 2015) 